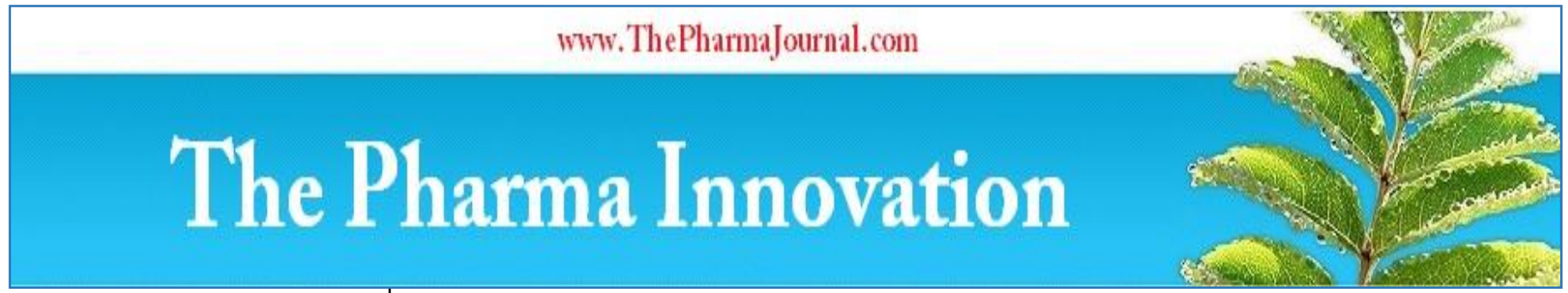

ISSN (E): 2277 - 7695

ISSN (P): 2349-8242

NAAS Rating: $\mathbf{5 . 0 3}$

TPI 2020; 9(6): 18-24

(C) $2020 \mathrm{TPI}$

www.thepharmajournal.com

Received: 12-04-2020

Accepted: 14-05-2020

Sanjay Kumar Jain

Ph.D Scholar, Nirma University,

Ahmedabad, Gujarat, India

Rajesh Kumar Jain

Professor- Operations

Management, Nirma University,

Ahmedabad, Gujarat, India
Corresponding Author:

Rajesh Kumar Jain

Professor- Operations

Management, Nirma University,

Ahmedabad, Gujarat, India

\section{Avoiding warning letters in pharmaceutical industry: A qualitative study in the Indian context}

\author{
Sanjay Kumar Jain and Rajesh Kumar Jain
}

DOI: https://doi.org/10.22271/tpi.2020.v9.i6a.4767

\begin{abstract}
The purpose of this paper is to identify the cause and effect of increased number of warning letters (www.fda.gov) issued by the Food and Drug Administration (FDA) of United States year after year in spite of clarity in the guidance published by the agency. Increased number of warning letters is matter of concern for the drug product / drug substance manufacturer, drug authority and end consumers (patients). Author identified six pharma professionals through their personal contacts and interviewed each of them. Poor quality management systems and lack of management oversight were found to be the key reasons for issuance of warning letters. Issuance of warning letters had adverse financial impact on business, delay in approvals thus loss of business opportunity and negative image of the organization among regulators, customers. Quality culture in the organization plays an important role to ensure regulatory compliance and building up the right quality culture in the organization is vital. Involvement of top management and participation in the management review meetings is essential for monitoring the compliance level in the organization.
\end{abstract}

Keywords: FDA, warning letter, quality culture, compliance

\section{Introduction}

FDA is USA based health regulatory agency (hereafter referred to as FDA) and is responsible for healthcare of the US citizens. As a part of verification of cGMP compliance, investigators from the agency perform inspections of the drug substance and drug product manufacturing sites. FDA Inspections are conducted for four reasons: (1) Pre-approval inspection (PAI) before approval of the drug product (2) Regular cGMP inspection and (3) Post approval \& Surveillance and (4) Cause Audit. During inspection, if any non-compliance is observed, the investigator issues the non-compliance observation on form-483 (Objectionable conditions cited by FDA on the Form No 483) and that is why the observations are popularly known as 483 observations. The manufacturer shall submit the response within 15 business days explaining the reason for existence of non-compliance, impact of the product quality and appropriate corrective action taken to avoid the recurrence. If the response is not satisfactory; non-compliance observations are critical in nature having direct impact on product quality, patient safety and data integrity, the FDA issues warning letters to the manufacturers. Number of warning letters issued by the FDA is increasing year after year in spite of clarity in the guidance issued by the agency. Increased number of warning letters is matter of concern for the manufacturer, drug authority and consumers. To study the reasons for issuance of the warning letters to Indian pharmaceutical manufacturers, authors interviewed six pharma professionals through their personal contacts with an objectives that how did they remediated the warning letters to satisfy FDA and what is their advice to industry friends.

\section{Literature review}

Ananth et al. (2018) reviewed FDA warning letters issued to pharmaceutical companies between "2015 to 2017". They concluded that there is an increase in warning letters in case of drugs and pharmaceuticals. They found that China and India got most warning letters from FDA followed by Korea, Canada and Japan. China and India together account for $80 \%$ of import alerts; which are associated with warning letters. Their review concluded that warning letters are increasing rapidly for drugs and formulations, whereas they were decreasing for medical devices and biologicals ${ }^{[1]}$. Khoja et al. (2016) reviewed warning letters issued to pharmaceutical drug manufacturers and found that Data integrity is main issue raised in most 
FDA warning letter, followed by failure to have computerized system with sufficient control to prevent unauthorized access or manipulation of data. Other non-compliances appearing in the warning letters are re-sampling and manipulation of old data, re-sampling was done without justification, altering time in record or changing system date and time ${ }^{[2]}$.

Unger (2019) in her review of warning letters for FY 2018 found another year of increase in the number of drug GMP warning letters issued by the FDA, though it is not as dramatic a difference as in some previous years. She found that China continues to lead as the country receiving the highest number of warning letters, as it did in FY2017. This year, it was found the addition of the Republic of (South) Korea to the countries whose companies received an increasing number of warning letters. Her review concluded that there was continued focus on data integrity and data governance by FDA [3]. Patel (2012) analysed selected warning letters of FDA sent to Indian and US pharmaceutical firms/manufacturers, and it was clear that Indian Pharma having most frequent deficiencies/non-compliance or deviations in the control producer of sterile drug product, design \& construction feature of buildings \& facilities and batch production and control records as compare to US Pharma. It was revealed that Indian Pharmaceuticals are stronger in the area of drug product testing \& release for distribution, laboratory control and quality assurance responsibilities as compare to US Pharma. Both the region companies (India and USA) are not giving adequate attention to investigation discrepancies/failures/out-of-specification (OOS) results and it's remained the dominant theme in the FDA warning letters. Deficiencies in the Quality System were the most frequent ones in Indian Pharma and US Pharma as appeared in the warning letters. Indian Pharma companies had higher finding concerning the Production System and Facilities \& Equipment System as compared to US Pharmaceuticals; while US Pharma companies shows more deviations in Laboratory Control System as compare to Indian Pharma. Based on the analysis, it could be concluded that FDA inspections are mainly focusing on the quality system, as the quality system provides the foundation for the manufacturing systems ${ }^{[4]}$.

Jain and Jain (2018) reviewed total 85 FDA warning letters issued from Jan 2014 to Dec 2016 and 26 out of 85 manufacturing sites were placed on Import alert and these manufacturers further cannot sale the products in USA market from affected sites. They identified that top four reasons for warning letters are Poor Quality system, Breach of Data Integrity, Poor Laboratory control and Poor production control. They suggested that other manufacturer involved in manufacturing of pharmaceutical drug product and drug substance shall regularly review these warning letters to learn to be proactive and implement the preventive actions to avoid the occurrence of the quality issues in their organization. It is evident from the review of warning letters for last three years that pharmaceutical industry need to improve quality systems specifically investigation system, Corrective Action and Preventive Action (CAPA) system, adherence to Standard Operating Procedure (SOP) compliance and sound stability program. There is need for Paradigm shift in quality culture and transparency ${ }^{[5]}$.

A forum of Gujarat Food and Drugs Administration (FDCA) and US Food and Drug Administration (USFDA) has been constituted for knowledge exchange and for information on new regulations, product safety issues and drug recalls.
During quarter meeting, country director in India for USFDA Dr Letitia Robinson with FDCA informed about 62 new guidelines, 475 new generic drug approval and 1035 drug recalls. They discussed that there has been a surge in the number of USFDA warning letters to Indian manufacturers and companies ${ }^{[11]}$.

\section{FDA inspection system}

The FDA's Drug Manufacturing Inspection Compliance Program is a system-based approach to inspection, and is very consistent with the robust quality system. FDA investigators are instructed to perform the inspection based on six systems categorised as (1) Quality system, (2) Production System, (3) Facilities and Equipment system, (4) Laboratory control system, (5) Materials system and (6) Packaging \& Labelling system. The Fig 1 shows the relationship among the six systems: the quality system and the five manufacturing systems. The quality system provides the foundation for the manufacturing systems that are linked and function within it. One of the important themes of the systems based inspection compliance program is that investigator can assess whether each of the systems is in a state of control. There has been a significant increase in the number of USFDA inspections of pharmaceutical manufacturing plants located in India in the past few years mainly due to the increase in the number of pre-approval inspections, routine GMP inspections and compliance follow-up activities. It has become clear that effective and efficient inspectional coverage has been crucial to the successful management of the foreign inspection program of FDA being resource-intensive nature and that can be achieved only through maintenance of consistency and uniformity of inspection and enforcement activities. The agency tries to utilize highly qualified Investigators and Analysts for the foreign inspection program; who have extensive experience in conducting drug inspections with demonstrated track records of working effectively in a tight time frame and under considerable pressure ${ }^{[6]}$.

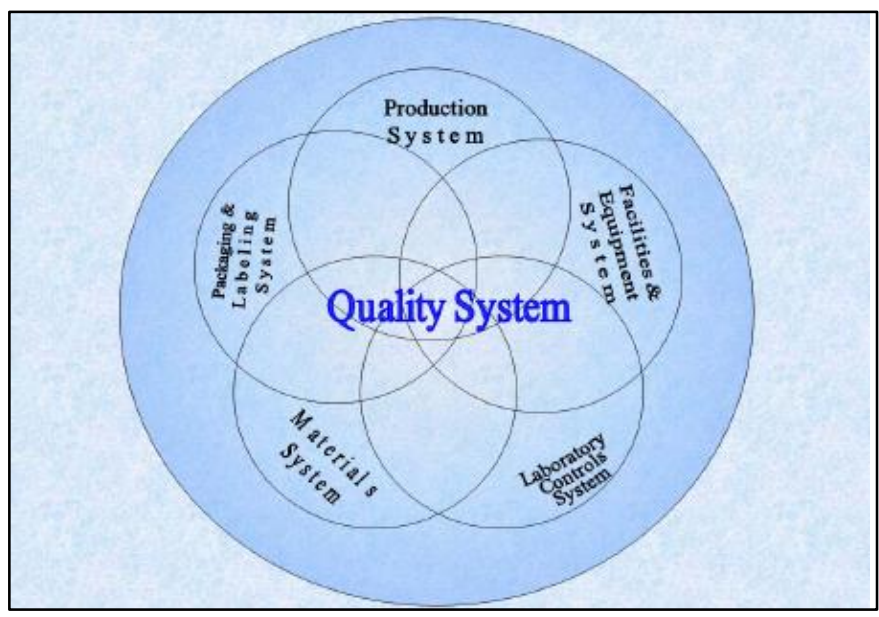

(Source: Reference \# 10 as listed in the article)

Fig 1: The Six-System Inspection Model

Quality system is always part of the inspection along with other system randomly selected by investigator(s) at their own discretion. Above comprehensive quality systems model, if implemented, will allow manufacturers to support and sustain robust, modern quality systems that are consistent with CGMP regulations. The overarching philosophy articulated in both the CGMP regulations and in robust modern quality systems is: Quality should be built into the product, and 
testing alone cannot be relied on to ensure product quality. FDA believes that the inherent flexibility of the CGMP regulations enable manufacturers to implement a quality system in a form that is appropriate for their specific operations ${ }^{[7]}$.

\section{FDA warning letters}

FDA ensures the quality of drug products, medical devices and dietary supplements by carefully monitoring compliance with Current Good Manufacturing Practice (CGMP) regulations. These regulations contain minimum requirements for the methods, facilities, and controls used in the manufacturing, processing and packing of a regulated product. In short, CGMP rules in essence ensure the safety of a product ${ }^{[8]}$.

When FDA finds that a manufacturer has significantly violated FDA regulations, FDA notifies the manufacturer in the form of a Warning Letter. The Warning Letter identifies the violation, such as poor manufacturing practices, poor laboratory practices, data integrity issues, problems with claims for what a product can do, or incorrect directions for use. The letter also makes clear that the company must correct the problem and provides directions and a timeframe for the company to inform FDA of its plans for corrective actions. FDA then checks to ensure that the company's proposed corrective actions are adequate ${ }^{[9]}$.

The FDA provides an electronic reading room on its website (www.fda.gov) that provides access to a great deal of useful information, including copies of Warning Letters issued by the FDA. Reviewing these letters can be useful because they provide insight into the inspection techniques and concerns of FDA inspectors. Understanding common violations mentioned in such notifications can prove beneficial to those firms undergoing inspections. Additionally, they can be used to perform gap analyses of the processes used in other organization in preparation for an FDA inspection.

\section{Interviews of pharma professionals}

In view of very high number of warning letters issued to Indian drug product / drug substance manufacturers, authors decided to conduct interviews of six pharmaceutical professionals working in different pharmaceutical organizations. These professionals have faced USFDA inspection multiple times and had experience of warning letter issued to their manufacturing site during their tenure. In addition to this, they were actively involved in the remediation program as a part of improving the quality systems in the organization in view of warning letter issued to their organization, improving the quality system and implementing the corrective actions to avoid the recurrence. Author developed questions (11) for the interview of these professionals. Questions were mainly focused on reason for warning letter (WL), role of Quality culture in the organization for issuance of WL, steps taken to strengthen the quality culture, measures taken to educate the employees, recruitment procedure to hire right person, involvement of management and message to their industry friends. Interviews of the professionals were conducted either through personal meetings or questions were sent through e-mail. Responses received from these pharma professionals were compiled as listed in the Appendix 1.

\section{Analysis, discussion and conclusion}

Authors summarised the response of each professional and the crux of the responses of all six respondents, along with key take away message are as below given in Table 1.

Table 1: Summary Responses

\begin{tabular}{|c|c|c|c|}
\hline S. No & Question & Crux of responses of all respondents & Key take away \\
\hline 1 & $\begin{array}{l}\text { What were the reasons for issuance of Warning letter and import } \\
\text { alert at your manufacturing site? }\end{array}$ & $\begin{array}{c}\text { Poor Quality Management systems and lack of } \\
\text { oversight of the management }\end{array}$ & $\begin{array}{l}\text { Improve Quality } \\
\text { Management } \\
\text { systems }\end{array}$ \\
\hline 2 & $\begin{array}{l}\text { How do you find the FDA guidelines in terms of their clarity of } \\
\text { expression, interpretation etc.? }\end{array}$ & $\begin{array}{l}\text { Guidelines are interpreted differently by different } \\
\text { person hence need clarity }\end{array}$ & $\begin{array}{l}\text { Correct } \\
\text { interpretation of } \\
\text { Guidelines }\end{array}$ \\
\hline 3 & $\begin{array}{l}\text { How was the Quality Culture in general in the plant, people are } \\
\text { for it, against it, too much pressurized, enthusiastic about the } \\
\text { state of quality affairs in the organization. }\end{array}$ & $\begin{array}{l}\text { Lack of Quality system } \\
\text { knowledge Priority to proc }\end{array}$ & $\begin{array}{l}\text { Quality before } \\
\text { productivity }\end{array}$ \\
\hline 4 & $\begin{array}{r}\text { Do you see that quality culture in the o } \\
\text { important role to ensure com }\end{array}$ & $\begin{array}{r}\text { Quality culture is directly } \\
\text { le }\end{array}$ & Right Quality culture \\
\hline 5 & $\begin{array}{l}\text { What steps shall be taken to build quality culture in the } \\
\text { organization? }\end{array}$ & Quality from top management and leaders is vital & $\begin{array}{r}\text { Quali } \\
\text { mar }\end{array}$ \\
\hline 6 & $\begin{array}{l}\text { What were the changes you brought in the organization to meet } \\
\text { the regulatory expectation and lifting the warning letter? }\end{array}$ & $\begin{array}{c}\text { Training of the employees, Improved proc } \\
\text { monitoring of work places has brought th } \\
\text { in the organization }\end{array}$ & $\begin{array}{l}\text { Monitoring of work } \\
\text { place }\end{array}$ \\
\hline 7 & $\begin{array}{l}\text { How do you find the knowledge, competency and attitude of the } \\
\text { people in India in general, in organizational context? }\end{array}$ & $\begin{array}{l}\text { Employees are competent and knowledgeable, } \\
\text { however the attitude need to changed towards } \\
\text { quality and data integrity }\end{array}$ & $\begin{array}{r}\text { Attitud } \\
\text { quality } \\
\text { int }\end{array}$ \\
\hline 8 & $\begin{array}{r}\text { What are the me } \\
\text { reg }\end{array}$ & Training of the em & \begin{tabular}{|c|}
$\begin{array}{c}\text { Effective Training of } \\
\text { the employees }\end{array}$ \\
\end{tabular} \\
\hline 9 & $\begin{array}{c}\text { Do you suggest that specific precautions shall be } \\
\text { while recruiting new people? }\end{array}$ & $\begin{array}{r}\text { The person with right } \\
\text { someon }\end{array}$ & $\begin{array}{c}\text { Referral of the } \\
\text { person having right } \\
\text { attitude }\end{array}$ \\
\hline 10 & $\begin{array}{r}\text { What do you suggest to have } \\
\text { to sustain compliance }\end{array}$ & $\begin{array}{r}\text { Periodic Management re } \\
\text { for success of }\end{array}$ & \begin{tabular}{c|} 
Periodic \\
Management review
\end{tabular} \\
\hline 11 & $\begin{array}{l}\text { What is the message you would like to give to other industry } \\
\text { friends to ensure compliance and avoid such notices (Warning } \\
\text { letter and import alert)? }\end{array}$ & $\begin{array}{l}\text { Following is the recommendations - } \\
\text { Quality first, Being proactive, Involvement of the } \\
\text { top management, Right person for right job, be } \\
\text { truthful and automation }\end{array}$ & $\begin{array}{l}\text { Proactive-ness and } \\
\text { automation }\end{array}$ \\
\hline
\end{tabular}


All the pharma professionals interviewed admitted that poor quality management systems and lack of management oversight resulted in the warning letter at their respective manufacturing site(s).

Quality culture of the organization plays an important role to ensure regulatory compliance. It was agreed by the professionals, that quality culture of the organization has direct impact on the quality and compliance. Building the right quality culture in the organization is vital and it shall have top down approach meaning that top management shall percolate the right quality culture down the line staff and workforce. As a part of remediation, most of them confirmed that they focused more on the effective training of the employees, processes were improved to avoid any error, invested heavy on automation to avoid any human error and make the system fool proof. They further confirmed that involvement of top management and participation in the management review meeting has improved the overall quality culture and compliance level in the organization. Authors suggest that other pharma manufacturer involved in drug product and drug substance shall be proactive and focus more on quality than quantity. Top management involvement at all the stages of manufacturing is going to have positive impact on the compliance level. Automation would further help in reducing human error, expedite the processes, and bring transparency in the organizations. There is need for Paradigm shift in quality culture and transparency in the organization. Firms need to exercise more laboratory control specifically for computerised system to avoid any manipulation and breach of data integrity. Any observation about breach of data integrity will shake the confidence and trust of regulator. Any findings about data integrity breach would result into stoppage of the business for USA market. Quality, compliance and integrity are the pillars for any pharmaceutical organization to be successful.

Based on review warning letter, Khoja (2016) concluded that data integrity is the main issue raised in the most FDA warning letters followed by inadequate control of computerised systems. Unger (2019) in her article concluded that there was continued focus on data integrity and data governance by FDA. Patel (2012) confirmed that deficiencies in quality system were the most frequent one in most of the warning letters both for US and India regions. Constitution of forum between USFDA and FDCA, Gujarat to discuss various update including the surge of warning letters to Indian pharma manufacturers supports our study. This paper based on the primary data, also supports the findings of Khoja, Unger and Patel.

\section{Limitation and future scope of the study}

The study includes interaction with the pharma professionals i.e. entrepreneur and senior management employees of the pharma companies from Gujarat and Maharashtra States, India only. Future Study can be conducted interviewing the professionals from other states of India and overseas countries. The future study can also involve the interaction with regulators of different countries like India, USA, UK, etc. The interview questions were qualitative in nature in the current study. Future study can include more questions including quantitative questions.

\section{Appendix 1: Responses of the professionals}

\begin{tabular}{|c|c|c|c|c|c|c|c|}
\hline S No & Question & Respondent 1 & Respondent 2 & Respondent 3 & Respondent 4 & Respondent 5 & Respondent 6 \\
\hline 1 & $\begin{array}{l}\text { What were the } \\
\text { reasons for issuance } \\
\text { of Warning letter and } \\
\text { import alert at your } \\
\text { manufacturing site? }\end{array}$ & $\begin{array}{c}\text { Failure of Quality } \\
\text { Management }\end{array}$ & $\begin{array}{l}\text { (a) Limited } \\
\text { Management } \\
\text { oversight. } \\
\text { (b) Lack of } \\
\text { complete } \\
\text { understanding of } \\
\text { US FDA } \\
\text { expectations. c. } \\
\text { Business taking } \\
\text { priority over } \\
\text { Compliance. }\end{array}$ & $\begin{array}{c}\text { The warning letter } \\
\text { was issued for data } \\
\text { integrity issues } \\
\text { noticed in } \\
\text { laboratory and } \\
\text { quality system. } \\
\text { There are serious } \\
\text { GMP issues in } \\
\text { terms of violations } \\
\text { in quality systems }\end{array}$ & \begin{tabular}{|} 
Failed to thoroughly \\
investigate OOS \\
laboratory results. Failed \\
to identify the root cause \\
to provide adequate \\
corrective actions. Did not \\
adequately investigate and \\
address consumer \\
complaints on multiple \\
occasions.
\end{tabular} & $\begin{array}{c}\text { Multiple types of Beta-lactam } \\
\text { molecules being handled at the } \\
\text { site. Management's } \\
\text { Unawareness about the } \\
\text { consequences of the changes } \\
\text { done at the facility and } \\
\text { handling multiple beta-lactam } \\
\text { types at the same site. There is } \\
\text { no such facility in the world. }\end{array}$ & $\begin{array}{c}\text { Warning Letter } \\
\text { has Clarity }\end{array}$ \\
\hline 2 & $\begin{array}{l}\text { How do you find the } \\
\text { FDA guidelines in } \\
\text { terms of their clarity } \\
\text { of expression, } \\
\text { interpretation etc.? }\end{array}$ & Somewhat clear. & $\begin{array}{c}\text { Yes indeed there are } \\
\text { several guidelines } \\
\text { which are general \& } \\
\text { vague \& hence } \\
\text { interpreted } \\
\text { differently by } \\
\text { different companies } \\
\text { in the Industry as } \\
\text { well as Inspection } \\
\text { personnel visiting } \\
\text { the site. }\end{array}$ & $\begin{array}{l}\text { The FDA guidance } \\
\text { need to be clearer } \\
\text { with respect to } \\
\text { expectations by } \\
\text { FDA. More times } \\
\text { the guidance does } \\
\text { not give clear } \\
\text { understanding } \\
\text { and/or instruction } \\
\text { for industry. This } \\
\text { leads to different } \\
\text { interpretation by } \\
\text { individuals or } \\
\text { industry }\end{array}$ & \begin{tabular}{|c|} 
FDA guideline reflects \\
about agency's current \\
thinking on the topic. \\
Guidelines are \\
recommendations. \\
Guidelines are never \\
prescriptive in nature \\
because different \\
organization can achieve \\
particular thing in different \\
ways. In view of this I feel \\
that guidelines are very \\
clear and lot of inputs go \\
before the draft guidelines \\
are converted into the final \\
guidelines.
\end{tabular} & $\begin{array}{l}\text { Guidelines have clarity. } \\
\text { However, the way it is } \\
\text { interpreted is different at times } \\
\text { by auditor. Also the criticality } \\
\text { assessment differs amongst } \\
\text { auditors. }\end{array}$ & $\begin{array}{c}\text { Open to } \\
\text { interpretation }\end{array}$ \\
\hline 3 & $\begin{array}{l}\text { How was the Quality } \\
\text { Culture in general in } \\
\text { the plant, people are } \\
\text { for it, against it, too } \\
\text { much pressurized, } \\
\text { enthusiastic about the } \\
\text { state of quality affairs } \\
\text { in the organization. }\end{array}$ & $\begin{array}{l}\text { People are mostly } \\
\text { for it. The reason } \\
\text { for some not for } \\
\text { it is because of } \\
\text { their lack of } \\
\text { knowledge and } \\
\text { understanding }\end{array}$ & \begin{tabular}{|} 
The Quality Culture \\
in the last 2 years \\
has dramatically \\
changed for the \\
better in the last 2 \\
years starting at the \\
lowest level \& \\
hence there is \\
enthusiasm \& \\
confidence. There is \\
a realisation that
\end{tabular} & $\begin{array}{l}\text { There was no } \\
\text { quality culture, the } \\
\text { entire organization } \\
\text { was behind } \\
\text { production work } \\
\text { pressure and the } \\
\text { quality was } \\
\text { interpreted / } \\
\text { moulded in such a } \\
\text { way that it suits } \\
\text { production output }\end{array}$ & \begin{tabular}{|} 
Quality culture is in \\
healthy state. People \\
across the organization \\
have understood that it is \\
essential for long term \\
survival and is pre- \\
requisite for doing \\
business. People across all \\
levels are supporting this \\
quality culture momentum. \\
People are positive about
\end{tabular} & $\begin{array}{l}\text { Work Culture at the } \\
\text { organisation reflects on the } \\
\text { Quality culture in General. } \\
\text { The balance between } \\
\text { productivity and precision is } \\
\text { always a challenge. Aspects } \\
\text { related to quality system } \\
\text { documentation are considered } \\
\text { additional task and } \\
\text { consequently debated. Most of } \\
\text { the people are not bothered }\end{array}$ & No Comments \\
\hline
\end{tabular}




\begin{tabular}{|c|c|c|c|c|c|c|c|}
\hline & & & $\begin{array}{c}\text { this mandatory if } \\
\text { you want to be in } \\
\text { this business. Some } \\
\text { pressure is } \\
\text { obviously felt as a } \\
\text { few things are } \\
\text { getting over done. }\end{array}$ & & $\begin{array}{c}\text { whole approach. There is } \\
\text { no additional pressure on } \\
\text { account of this. People are } \\
\text { enthusiastic however } \\
\text { motivation and/or } \\
\text { continuous dialogue with } \\
\text { all concerned at all levels } \\
\text { are essential. } \\
\end{array}$ & $\begin{array}{l}\text { about quality, they are more } \\
\text { concerned about completing } \\
\text { the task in hand. }\end{array}$ & \\
\hline 4 & $\begin{array}{l}\text { Do you see that } \\
\text { quality culture in the } \\
\text { organization plays } \\
\text { important role to } \\
\text { ensure compliance? }\end{array}$ & Yes & $\begin{array}{c}\text { Culture of quality } \\
\text { from Senior } \\
\text { Management which } \\
\text { should percolate to } \\
\text { the last man in the } \\
\text { organisation is one } \\
\text { of the key elements } \\
\text { for sustainable } \\
\text { compliance. }\end{array}$ & $\begin{array}{c}\text { The quality culture } \\
\text { of company } \\
\text { decides compliance } \\
\text { level }\end{array}$ & $\begin{array}{l}\text { I consider compliance as } \\
\text { minimum regulatory } \\
\text { requirement. Quality } \\
\text { culture is therefore more } \\
\text { than just compliance. It is } \\
\text { definitely helping the } \\
\text { organization is its business } \\
\text { goals. }\end{array}$ & Yes. & Yes \\
\hline 5 & $\begin{array}{c}\text { What steps shall be } \\
\text { taken to build quality } \\
\text { culture in the } \\
\text { organization? }\end{array}$ & \begin{tabular}{|} 
Demonstrate that \\
Quality is an \\
important aspect \\
for the company \\
from the Top \\
Management and \\
put Systems and \\
Processes that \\
will ensure \\
emphasis on \\
Quality at each \\
stage in the \\
organization
\end{tabular} & \begin{tabular}{|c|} 
Management has \\
taken the following \\
initiatives to ensure \\
sustainability: \\
Leadership changes, \\
No Tolerance \\
Policy, External \\
SME, Quality \\
Governance \\
Enhancement, \\
Effective QRM, \\
IPQA introduction, \\
QC reviewers, \\
Compliance team, \\
Investigation team, \\
Biometric \\
Attendance system, \\
Open house \\
sessions
\end{tabular} & \begin{tabular}{|} 
The top \\
management in the \\
industry need to \\
understand that \\
business comes \\
from quality \\
culture only. The \\
Top management \\
need to trained for \\
understanding of \\
quality and GMP
\end{tabular} & \begin{tabular}{|} 
Emphasis on quality by \\
senior leaders, Ensuring \\
message credibility, \\
Increasing employee \\
oversight and \\
empowerment, Reward \\
and recognise quality \\
excellence, Establish \\
environment of Trust and \\
collaboration, Science \\
based decision making
\end{tabular} & $\begin{array}{c}\text { Make people understand } \\
\text { individual responsibility and } \\
\text { accountability towards quality. } \\
\text { This needs subtle but rigorous } \\
\text { dialogue with each individual } \\
\text { - through training sessions } \\
\text { and day to day interaction. } \\
\text { Acknowledging /recognizing } \\
\text { acts that reflect desired } \\
\text { behaviour. The decisions } \\
\text { taken by the Site and } \\
\text { Corporate Management (that } \\
\text { are for all to see) should } \\
\text { reflect commitment to } \\
\text { developing the quality culture. }\end{array}$ & $\begin{array}{l}\text { Top down } \\
\text { approach }\end{array}$ \\
\hline 6 & $\begin{array}{c}\text { What were the } \\
\text { changes you brought } \\
\text { in the organization to } \\
\text { meet the regulatory } \\
\text { expectation and } \\
\text { lifting the warning } \\
\text { letter? }\end{array}$ & \begin{tabular}{|} 
Awareness \\
among the team \\
on the impact of \\
quality failures. \\
Ensured right \\
people are doing \\
the right jobs. \\
Revamped the \\
QMS and made it \\
user friendly. \\
Frequent \\
Trainings. \\
Introspection on \\
the cause of the \\
Quality failure \\
and put effective \\
remedial actions
\end{tabular} & \begin{tabular}{|} 
Over the last more \\
than 2 years we \\
have taken a \\
extensive \\
remediation \\
program at the site \\
which includes the \\
following: \\
Procuring or \\
replacement of all \\
equipment to ensure \\
21CFR compliance. \\
Hiring expert \\
consultants to help \\
develop systems, \\
processes \\
comparable to the \\
best in the Industry. \\
Intensive \\
Management \\
involvement \& \\
oversight on \\
Compliance issues. \\
Engagement, \\
training \& \\
education of \\
personnel at all \\
levels to meet \\
current \& ever \\
changing \\
Regulatory \\
expectations.
\end{tabular} & \begin{tabular}{|} 
We changed the \\
structure where in \\
true sense the \\
quality is made \\
independent of \\
other function. \\
Training provided \\
to change the \\
culture, \\
independent \\
training department \\
started. Whistle \\
blower policy \\
made and all the \\
people are \\
encouraged to \\
report GMP issues.
\end{tabular} & $\begin{array}{c}\text { Lot of focus was given in } \\
\text { creating proper } \\
\text { investigation teams. Proper } \\
\text { training was given about } \\
\text { how to use different tools } \\
\text { during investigation. All } \\
\text { consumer complaint } \\
\text { investigations were } \\
\text { revisited to find out any } \\
\text { gaps in the investigation. } \\
\text { Appropriate actions were } \\
\text { initiated depending upon } \\
\text { outcome of re- } \\
\text { investigation of customer } \\
\text { complaints. FDA } \\
\text { observations were applied } \\
\text { holistically for other } \\
\text { products and processes. } \\
\text { More focus was given on } \\
\text { risk assessment and CAPA } \\
\text { implementation / } \\
\text { effectiveness. Focus was } \\
\text { given for quality culture } \\
\text { building. "GEMBA" walk } \\
\text { is way of life now across } \\
\text { all locations. }\end{array}$ & $\begin{array}{c}\text { Appropriate controls with } \\
\text { respect to personnel } \\
\text { movement and API storage } \\
\text { and dispensing were the major } \\
\text { changes. Leave aside lifting } \\
\text { warning letter or ban, the } \\
\text { management agreed to the } \\
\text { consent decree and since then } \\
\text { we have not supplied to US } \\
\text { market. However, the steps } \\
\text { taken by Site management } \\
\text { have been found acceptable to } \\
\text { all other regulatory agencies } \\
\text { and we continue to supply to } \\
\text { about } 130 \text { countries. }\end{array}$ & $\begin{array}{l}\text { Worked on the } \\
3 \text { Ps- People, } \\
\text { Process, } \\
\text { Procedures }\end{array}$ \\
\hline 7 & $\begin{array}{l}\text { How do you find the } \\
\text { knowledge, } \\
\text { competency and } \\
\text { attitude of the people } \\
\text { in India in general, in } \\
\text { organizational } \\
\text { context? }\end{array}$ & \begin{tabular}{|} 
It is very good. \\
Only thing we \\
need to \\
Channelize the \\
knowledge by \\
giving them the \\
right environment \\
and ensure people \\
with the right \\
attitude towards \\
Quality are part \\
of the team \\
\end{tabular} & \begin{tabular}{|} 
There is sufficient \\
knowledge \& \\
competency within \\
India comparable \\
with the best in the \\
world. However this \\
number is very \\
small \& demand \\
from the Industry \\
has increased \\
substantially. Hence \\
there is a shortage
\end{tabular} & $\begin{array}{l}\text { The individuals are } \\
\text { having great } \\
\text { capacity, } \\
\text { knowledge and } \\
\text { competency. The } \\
\text { only change } \\
\text { required in attitude. }\end{array}$ & \begin{tabular}{|} 
There is no gap as far as \\
knowledge and \\
competency is considered. \\
However most of the time \\
we lack is implementing \\
the knowledge which we \\
have. Implementation at \\
times is not consistently \\
applied. "JUGAD" and \\
"CHALTA HAI" attitude \\
still prevails in some \\
organization which is not
\end{tabular} & $\begin{array}{l}\text { People have the knowledge. } \\
\text { Competency and attitude is } \\
\text { pathetic. }\end{array}$ & $\begin{array}{c}\text { Individuals are } \\
\text { Knowledgeable, } \\
\text { Competent. } \\
\text { Employee } \\
\text { Attitude is not } \\
\text { to be } \\
\text { questioned; } \\
\text { prime is the } \\
\text { Management } \\
\text { support and } \\
\text { efforts }\end{array}$ \\
\hline
\end{tabular}




\begin{tabular}{|c|c|c|c|c|c|c|c|}
\hline & & & \begin{tabular}{|c|} 
in the Industry of \\
skilled \& \\
knowledgeable \\
people \& hence \\
several companies \\
are not able to \\
higher the right \\
people \& do the \\
right thing. Attitude \\
$\&$ Culture is still a \\
problem, however it \\
is changing \& in the \\
next 2 to 3 years, \\
we should be able to \\
see that compare \\
with the best in the \\
world.
\end{tabular} & & acceptable practice. & & \\
\hline 8 & $\begin{array}{c}\text { What are the } \\
\text { measures you } \\
\text { initiated to educate } \\
\text { the staff on regular } \\
\text { basis during your } \\
\text { tenure? }\end{array}$ & \begin{tabular}{|} 
Internal \\
Trainings. \\
Emphasising the \\
overall impact \\
due to failure of \\
QMS at each and \\
different stage of \\
product life cycle. \\
Ensure checks \\
and measures at \\
each stages. \\
Emphasis more \\
on Self Audits
\end{tabular} & \begin{tabular}{|} 
Besides Training we \\
have engaged \\
external SME's who \\
visit the site \\
periodically \& \\
interact with the \\
team in terms of \\
best practices, \\
trends etc
\end{tabular} & \begin{tabular}{|c|} 
Manual systems \\
stopped and more \\
software based \\
approach \\
introduced. The \\
departments are \\
made independent \\
and empowered to \\
take decisions. \\
Separate training \\
department started \\
with two year \\
calendar. External \\
agencies are \\
involved for \\
training. Focus \\
changed from \\
quantity product to \\
quality product
\end{tabular} & $\begin{array}{c}\text { More focus is given on } \\
\text { training, More focus is } \\
\text { given on SOP compliance, } \\
\text { "GEMBA" walk to } \\
\text { connect with shop floor } \\
\text { people, Learning from } \\
\text { mistakes of others, Use of } \\
\text { more visual displays } \\
\text { conveying specific cGMP } \\
\text { requirements. }\end{array}$ & $\begin{array}{c}\text { Regular monitoring of the day } \\
\text { to day activity and individual } \\
\text { guidance. }\end{array}$ & $\begin{array}{l}\text { Training and } \\
\text { Mentoring }\end{array}$ \\
\hline 9 & $\begin{array}{l}\text { Do you suggest that } \\
\text { specific precautions } \\
\text { shall be exercised } \\
\text { while recruiting new } \\
\text { people? }\end{array}$ & \begin{tabular}{|} 
Need to ensure \\
people with the \\
right attitude \\
towards quality \\
are chosen. The \\
interview should \\
be based on \\
asking answers \\
for real life cases. \\
See the \\
candidates \\
responses \\
towards a created \\
quality issue \\
\end{tabular} & $\begin{array}{c}\text { The usual internal } \\
\text { interview process is } \\
\text { followed by multi } \\
\text { department senior } \\
\text { leaders, } \\
\text { Additionally we } \\
\text { have now hired a } \\
\text { consultant whose } \\
\text { expertise is to } \\
\text { profile individuals } \\
\text { through intelligence } \\
\text { gathering before } \\
\text { hiring or } \\
\text { immediately after } \\
\text { hiring. }\end{array}$ & \begin{tabular}{|} 
No, in fact the \\
system should be \\
available that the \\
individual cannot \\
take decision \\
without violating \\
GMP
\end{tabular} & $\begin{array}{c}\text { The people who change } \\
\text { job frequently should not } \\
\text { be recruited. If someone } \\
\text { changes job frequently, } \\
\text { then there is no } \\
\text { commitment towards } \\
\text { organizational } \\
\text { requirement. If you need to } \\
\text { contribute then you need } \\
\text { to stay for some time with } \\
\text { organization. Attitude of } \\
\text { the candidate shall be } \\
\text { evaluated properly. }\end{array}$ & Yes. Reference is better. & No. \\
\hline 10 & $\begin{array}{l}\text { What do you suggest } \\
\text { to have increased } \\
\text { management } \\
\text { oversight to sustain } \\
\text { compliance and } \\
\text { business continuity? }\end{array}$ & \begin{tabular}{|} 
Management \\
Review Meetings \\
initially monthly \\
and then quarter \\
wise. Discussions \\
of findings of the \\
Self Inspection \\
(done once in 6 \\
months) by the \\
Management. \\
Hold Senior \\
Leadership \\
Accountable for \\
any failures of \\
QMS
\end{tabular} & \begin{tabular}{|c|} 
Quality review \\
meeting is now \\
being done on a \\
monthly basis \& \\
minimum 1 director \\
from the board is \\
present. SMEs have \\
been appointed to \\
visit on bi-monthly \\
basis to check on \\
the work done by \\
the team \& give a \\
report to the \\
management from a \\
compliance \\
perspective. Third \\
party audits \& \\
internal audit \\
process has been \\
strengthened. \\
Automation \\
wherever possible \\
$\&$ budget permitting \\
is being \\
implemented.
\end{tabular} & $\begin{array}{c}\text { The MRM should } \\
\text { be every moth at } \\
\text { length and only } \\
\text { quality discussion. } \\
\text { Normally MR get } \\
\text { carried away with } \\
\text { productivity and } \\
\text { company loss. }\end{array}$ & $\begin{array}{c}\text { Strong periodic Quality } \\
\text { review meetings, Strong } \\
\text { monitoring of quality } \\
\text { metrics by senior } \\
\text { management, Talk about } \\
\text { quality by senior } \\
\text { management at all forums, } \\
\text { Less focus on numbers }\end{array}$ & $\begin{array}{l}\text { Oversight alone does not help. } \\
\text { It only creates anxiety and } \\
\text { panic. Management should } \\
\text { show resolve to address } \\
\text { technical and personnel } \\
\text { problems and enhancing } \\
\text { competency for sustained } \\
\text { compliance and business } \\
\text { continuity. }\end{array}$ & $\begin{array}{c}\text { Accept the facts } \\
\text { and take timely } \\
\text { action, issues } \\
\text { raised by site } \\
\text { and corporate in } \\
\text { management } \\
\text { review } \\
\text { meetings. } \\
\text { Record the } \\
\text { highlighted } \\
\text { problems and } \\
\text { resolve with a } \\
\text { root cause and } \\
\text { CAPA. }\end{array}$ \\
\hline 11 & $\begin{array}{l}\text { What is the message } \\
\text { you would like to } \\
\text { give to other industry } \\
\text { friends to ensure }\end{array}$ & $\begin{array}{c}\text { Quality is an } \\
\text { important aspect } \\
\text { during the } \\
\text { complete Life }\end{array}$ & $\begin{array}{c}\text { Take proactive } \\
\text { interest in } \\
\text { compliance matters } \\
\text { as one bad Agency }\end{array}$ & \begin{tabular}{|c|}
$\begin{array}{c}\text { There will short } \\
\text { term pain of } \\
\text { investigation if you } \\
\text { are following GMP }\end{array}$ \\
\end{tabular} & \begin{tabular}{|} 
Work on following aspects \\
- Do automations to the \\
extent positive. This will \\
avoid human errors. This
\end{tabular} & $\begin{array}{l}\text { No message to industry } \\
\text { friends. The notices are due to } \\
\text { the subtle messages taken by } \\
\text { site management from the }\end{array}$ & \begin{tabular}{|} 
WL and IA are \\
not one-day \\
action. If the \\
organisation has
\end{tabular} \\
\hline
\end{tabular}




\begin{tabular}{|c|c|c|c|c|c|c|}
\hline $\begin{array}{c}\text { compliance and avoid } \\
\text { such notices } \\
\text { (Warning letter and } \\
\text { import alert)? }\end{array}$ & \begin{tabular}{|} 
Cycle of any \\
Product. The \\
Importance of \\
Quality should \\
percolate from \\
the Top \\
Management and \\
they should be \\
accountable. \\
Have a Robust \\
and fool proof \\
Quality \\
Management \\
System in the \\
organisation and \\
ensure everyone \\
Strictly follow \\
the same. Have \\
the right people \\
doing the right \\
jobs. Be truthful. \\
All issues and \\
deviations can be \\
handled through \\
proper CAPA
\end{tabular} & \begin{tabular}{|} 
inspection can have \\
a cascading effect \& \\
the company can be \\
set behind by a few \\
years. To have an \\
independent view, \\
engage with \\
qualified external \\
SME's on long term \\
basis to visit the \\
site, review \\
compliance status, \\
and engage with \\
employees to ensure \\
sustainable \\
compliance. Invest \\
in systems \& \\
process.
\end{tabular} & $\begin{array}{c}\text { but in long term it } \\
\text { will avoid more } \\
\text { pains. }\end{array}$ & \begin{tabular}{|c|} 
will also result into \\
reproducibility (less \\
variation) of the process, \\
At the same time, we \\
cannot overlook human \\
aspect at all. Therefore \\
focus on recruitment of \\
right people. Train them \\
properly and retain good \\
people., Do not just focus \\
about data integrity issues \\
in laboratory. Extend it to \\
production, engineering, \\
warehouse etc. FDA now \\
already started focusing \\
these areas also for data \\
integrity., Do not look at \\
each failure as discrete \\
incident rather than \\
looking across all the data \\
(quality metrics) and \\
recognise trends and \\
relationship between the \\
data., Facilitate continual \\
improvement., Facilitate \\
science based risk based \\
decision making as overall \\
way of working.
\end{tabular} & \begin{tabular}{|c|} 
owner of the organization / \\
higher management \\
considering compliance issues \\
that lead to business losses. \\
The message would be to the \\
higher management to \\
consider pharmaceutical \\
business with a pinch of salt \\
when compliance aspects \\
imply business losses and \\
empower employees to take \\
decisions to ensure \\
compliance first.
\end{tabular} & $\begin{array}{c}\text { erred in past } \\
\text { and the filings } \\
\text { and the } \\
\text { marketed } \\
\text { products are } \\
\text { having the } \\
\text { deviations, } \\
\text { OOS, Non- } \\
\text { compliances, } \\
\text { Data Integrity } \\
\text { Breaches need } \\
\text { to be recorded } \\
\text { as on date } \\
\text { informed to } \\
\text { FDA, FAR. } \\
\text { Further need to } \\
\text { be investigated } \\
\text { and RCA and } \\
\text { CAPA arrived } \\
\text { at. Organisation } \\
\text { wide CAP } \\
\text { (Corrective } \\
\text { Action Plan) to } \\
\text { be developed as } \\
\text { a Remediation } \\
\text { Action. }\end{array}$ \\
\hline
\end{tabular}

Source: Authors compilation based on Interaction with pharma professionals

\section{References}

1. Ananth L, Gurbani NK, Kumar S, Gujavarti B, "A retrospective study of Warning Letters issued by US FDA over 2015-2017', International Journal of Drug Regulatory Affairs. 2018; 6(2):48-53

2. Khoja SS, Khoja S, Chauhan PH, Khoja FS. "A review on USFDA warning letter and violation observed in Pharmaceutical Industry", Pharma Tutor. 2016; 4(12):3336

3. Unger Barbara. An Analysis of FDA FY2018 Drug GMP Warning Letters, 2019.

(https://www.pharmaceuticalonline.com/doc/an-analysisof-fda-fy-drug-gmp-warning-letters-0003)

4. Patel DS. FDA Warning Letter Analysis: A Tool for GMP Compliance. Int J Pharm Sci Res. 2012; 3(12):4592-4603.

5. Jain Sanjay Kumar, Jain Rajesh Kumar. Review of FDA Warning Letters to Pharmaceuticals: Cause and Effect Analysis. Research J. Pharm. and Tech. 2018; 11(7):3219-3226

6. https://www.fda.gov/iceci/inspections/inspectionguides/u cm075021.htm (Accessed on 16 Sept 2017)

7. Guidance for Industry Quality Systems Approach to Pharmaceutical CGMP Regulations, U.S. Department of Health and Human Services Food and Drug Administration, September 2006, Pharmaceutical CGMP Regulations

8. Rozembajgier Mike. "FDA Warning Letters What Can Be Learned?", Pharmaceutical Processing, NOV/DEC, 2012, 42-43

9. https://www.fda.gov (Accessed on 07 July 2019)

10. Friedman Rick, "Pharmaceutical Quality Systems: US Perspective", Office of Manufacturing and Product Quality Center for Drug Evaluation and Research [https://www.fda.gov/media/82570/download (accessed on 07 July 2019)]

11. "USFDA, FDCA Joint Panel Formed" (2019), The Times of India, Ahmedabad edition, Thursday, July 2019, page 4. 